\title{
What's at stake in Doha climate talks
}

\author{
Negotiators look beyond the Kyoto Protocol and focus on 2020.
}

\author{
Jeff Tollefson
}

23 November 2012

Diplomats from around the world will gather for the United Nations (UN) climate talks next week in Doha, Qatar, where negotiators hope to agree a second phase of the Kyoto Protocol and lay the groundwork for a new global treaty that will take force by 2020. Nature takes a look at what is expected from the $18^{\text {th }}$ annual Conference of the Parties (COP 18), which runs from 26 November to 7 December.

\section{What is happening with the Kyoto Protocol?}

At last year's meeting in Durban, South Africa, the big showdown was over the future of Kyoto, and the talks very nearly imploded. Most industrialized countries were ready to move beyond the protocol and negotiate a new treaty altogether once the current commitment period comes to a close at the end of the year. But in the end, a block of developing countries allied itself with Europe and successfully fought for a second round of commitments. This means that parties to the protocol must now register

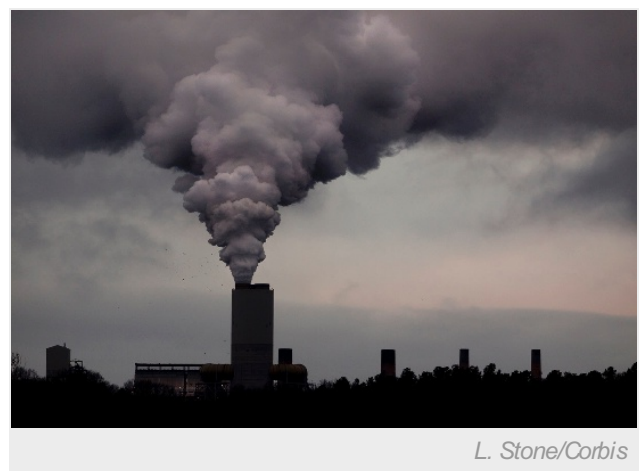

Countries are split on whether any future agreement on reducing greenhouse gas emission should be legally binding or voluntary. their commitments — political pledges at the moment — within a legally binding agreement. The goal for COP 18 is to complete that process and define the terms of the second commitment period, 'Kyoto II', which could last between five and eight years.

\section{Who will be involved in Kyoto II?}

The United States never ratified the Kyoto Protocol and has made it clear that it has no interest in going down that track now. Japan, Russia and Canada have all ducked out of a second round, but the ground is still shifting. Earlier this month New Zealand dropped out, and Australia announced that it would take part. As for the developing countries, where virtually all of the growth in emissions is taking place, the Kyoto framework requires nothing in the way of emissions reductions from them. As a result, the legal obligations under Kyoto II would apply to a small share of the global emissions - less than $15 \%$ of the total, according to UN officials.

\section{How does Kyoto II relate to the new treaty that is being negotiated?}

For now, Kyoto II will serve as little more than an interim measure, but many developing countries would like to make it the basis of the future treaty. But the main focus of the talks is what comes next. The UN climate negotiators have committed to signing a new treaty by 2015 , to take effect by 2020 - or possibly earlier if countries pushing for more ambitious action, such as the Maldives, get their way.

\section{What will this agreement look like?}

It's too early to say. Climate negotiators began to break down the dichotomy between developed and developing countries at the summit in Copenhagen, Denmark, in 2009. Not only did most countries step forward with pledges, but emerging giants such as China and Brazil signed a controversial agreement — dubbed the Copenhagen Accord — with the United States and other major industrialized countries that sought to assemble climate pledges under an entirely new framework. Affirmed a year later in Cancun, Mexico, this framework agreement incorporates signatories' climate commitments, but it is not legally binding. The legal force of the coming treaty is a key question.

\section{What does 'legally binding' mean?}

There are certain penalties for noncompliance with the Kyoto Protocol, including formal judgements and fines, but they are targeted at countries that want to participate. But there are few repercussions if a country drops out altogether — as Canada did last year. So public pressure will always be crucial for ensuring that countries do what they say they are going to do.

The Durban talks very nearly foundered on these questions last year. In the end, negotiators abandoned the words "legally binding" in favour of a vague commitment to negotiate "a protocol, another legal instrument or an agreed outcome with legal force". This leaves the door wide open. So far, the question has often been framed as a choice between a legally binding Kyoto-style framework and a voluntary Copenhagen-style framework, but many wonder whether there could be something in between. Negotiators in Doha will be 
exploring these questions as they create a road map to 2015.

\section{What else is on the COP 18 agenda?}

Negotiators will also seek to push forward work on climate adaptation and deforestation and will be wrangling over financial commitments. Developed countries seem to be largely on track to meet their Copenhagen commitments to fast-track US\$30 billion in climate aid from 2010-12, according to the Washington-based World Resources Institute, but assessments vary. It is also unclear how they will ramp up funding to the committed $\$ 100$ billion annually by 2020 .

\section{What about the goal of limiting global warming to $2^{\circ} \mathrm{C}$ ?}

There is widespread acknowledgement that the world is on a path to miss that target. A recent assessment conducted on behalf of the World Bank suggests that the world is currently on track for 4 degrees of warming, with potentially disastrous consequences. This week the United Nations Environment Programme issued its annual Emissions Gap report and found that emissions are set to rise to 58 gigatonnes of carbon dioxide equivalent by 2020 under a "business-as-usual" scenario, which is roughly 14 gigatonnes higher than they need to be in order to maintain a "likely" chance of staying below 2 degrees of warming. Current policies will help reduce the size of the gap, but UNEP nonetheless estimates that these efforts will fall short by 8-13 gigatonnes in 2020 .

In Doha, all eyes will be on the world's largest greenhouse-gas emitters — the United States and China — following the re-election of President Barack Obama and the appointment of $X$ Jinping as the new leader of China's Communist Party. But climate policies are not expected to change substantially in either country. More broadly, there is little evidence that the global political ambitionfor aggressive action combating climate change is going to increase any time soon.

Nature | doi:10.1038/nature.2012.11844 